\author{
Романишин А. кандидат педагогічних наук, \\ доиент Національна академія сухопутних військ \\ імені гетьмана Петра Сагайдачного \\ ORSID0000-0003-3115-5999 \\ Неурова А. кандидат психологічних наук, \\ Начіональна академія сухопутних військ \\ імені гетьмана Петра Сагайдачного \\ ORSID: 0000-0002-1220-8613
}

\title{
ПСИХОЛОГО-ПЕДАГОГІЧНІ УМОВИ ВИКЛАДАННЯ НАВЧАЛЬНОӤ ДИСЦИПЛІНИ «МОРАЛЬНО-ПСИХОЛОГІЧНЕЗАБЕЗПЕЧЕННЯ» У ВИЩИХ ВІЙСЬКОВИХ НАВЧАЛЬНИХ ЗАКЛАДАХ
}

\begin{abstract}
У статті представлені результати аналізу основних психолого-педагогічних умов ефективноі організації викладання навчальної дисиипліни «Морально-психологічне забезпечення» в процесі підготовки майбутніх військових фахівців у вищих військових навчальних закладах Міністерства оборони України та визначені иляхи досягнення ефективності реалізаиії психолого-педагогічних умов організаиії ї̈ викладання.

Ключові слова: навчальна дисципліна; морально-психологічне забезпечення; підготовка; професійна діяльність офічера; психолого-педагогічна діяльність; психолого-педагогічні умови; викладання; готовність.
\end{abstract}

Постановка проблеми. Життя не один раз доводило справедливість твердження: «Які офіцери - така і армія». Тож які повинні бути професійні якості офіцера? Від яких чинників вони залежать? Що необхідно робити для розкриття особистісного потенціалу офіцера? Відповіді на ці запитання повинні бути ключовою ланкою усієї реформи армії.

В умовах проведення Операції об’єднаних сил на території Луганської та Донецької областей, військової реформи, що проводиться, зростає значення моральнопсихологічного чинника, який здійснює безпосередній вплив на рівень національної безпеки України. Це зумовлює необхідність пошуку ефективних способів підтримки на високому рівні морального духу i психологічної стійкості особового складу. Особлива роль у вирішенні цього важливого завдання відводиться вищим військовим навчальним закладам (ВВНЗ) Міністерства оборони України, які повинні готувати фахівців, що володіють глибокими знаннями, міцними навичками і вміннями щодо теорії і практики морально-психологічного забезпечення (МПЗ) діяльності військовослужбовців.

Вирішення цього завдання передбачає наявність у офіцерів якостей, які визначають сутність їх службової діяльності і відповідають сучасним вимогам. Це, перш за все, патріотизм, вірність присязі і військовому обов'язку, професіоналізм тощо. I, нарешті, висока загальна культура, широка ерудиція, етична чистота i педагогічна досконалість[1].

Але, практика, у т.ч. i бойова, показує, що часто молодий офіцер не готовий до ефективного вирішення завдань, поставлених перед ним.

Аналіз відгуків із військ про проходження служби молодими офіцерами протягом першого року служби виявив, що рівень їхньої підготовки до виконання посадових обов'язків значно нижчий від потрібного. Офіцери - вчорашні випускники вищих військових навчальних закладів часто не мають достатніх професійних знань, навичок та умінь, необхідних морально-ділових якостей. Не можна не побачити низької психологопедагогічної підготовленості багатьох офіцерів-випускників. Результати військової практики свідчать, що значна частина офіцерів після закінчення навчальних закладів не підготовлені до самостійної роботи з людьми. Подолання нетактовного, зневажливого ставлення до 


\section{Питання психології}

підлеглого має принципове значення. Таке ставлення командира до підлеглого суперечить характеру сучасного бою, для успіху якого необхідна їх взаємна довіра. Подібні випадки під час виконання бойових завдань військовослужбовцями у зоні проведення Операції об'єднаних сил підтверджують цей висновок. Покора, яка грунтується тільки на страху покарання, має обмежений характер.

Аналіз останніх досліджень i публікацій. На нашу думку, під час навчання курсантів у військових навчальних закладах недостатньо уваги приділяють питанням їхньої підготовки до роботи 3 особовим складом. Наприклад, як виявило опитування (335 офіцерів-випускників 2018 року, що становить 97,1\% від загальної кількості офіцерів-випускників), яке проводило Головне управління моральнопсихологічного забезпечення ЗС України спільно 3 кафедрою моральнопсихологічного забезпечення діяльності військ Національної академії сухопутних військ імені гетьмана Петра Сагайдачного у вересні 2018 року, тільки 57\% опитаних офіцерів заявили, що одержана ними підготовка у ВВНЗ дає змогу повністю виконувати обов'язки за своїм фахом. I це, незважаючи на максималізм у висловлюваннях та завищену самооцінку, що притаманні молодим офіцерам. Ще нижче вони оцінювали свої спроможності виконувати обов'язки 3 організації i проведення заходів моральнопсихологічного забезпечення $(34,3 \%)$ та 3 питань керівництва повсякденною діяльністю підрозділу (50,1\%), що свідчить про недостатній рівень відповідної підготовки з цих питань у ВВНЗ. Про це свідчить і кількість правопорушень, які скоюють військовослужбовці під час проходження служби. На нашу думку, причини більшості порушень військової дисципліни пов'язані передусім із недостатньою професійною підготовленістю молодих командирів підрозділів, їхнім невмінням формувати у підлеглих необхідний морально-психологічний стан, підтримувати статутний порядок.

Аналіз психолого-педагогічної літератури останніх років свідчить, що процес готовності офіцерів до організації та проведення заходів МПЗ в умовах ведення антитерористичної операції операції об'єднаних сил не був предметом дослідження українських учених.

Мета статті. Мета статті полягає у теоретичному аналізі наукових джерел із досліджуваної проблеми, визначення шляхів досягнення ефективності реалізації психолого-педагогічних умов організації викладання навчальної дисципліни «Морально-психологічне забезпечення» в процесі підготовки майбутніх військових фахівців у вищих військових навчальних закладах Міністерства оборони України

Методи дослідження. На підставі аналізу наукових досліджень за допомогою емпіричних методів: спостереження, опитування та анкетування, ми виявили, що проблематика організації якісної підготовки майбутніх офіцерів, які б володіли глибокими знаннями, міцними навичками і вміннями щодо організації та проведення заходів МПЗ у військових підрозділах, не розглядалась.

Виклад основного матеріалу. Нами на основі аналізу досвіду, в т.ч. й власного, застосування військ в ході проведення Операції об’єднаних сил та якості організації морально-психологічного забезпечення діяльності військовослужбовців виявлено, що існують суттєві проблеми в організації якісної підготовки офіцерів, які б володіли глибокими знаннями, міцними навичками i уміннями в царині теорії i практики організації МПЗ діяльності підрозділів. Відповідно, метою нашої публікації $\epsilon$ розгляд основних психолого-педагогічних умов ефективної організації викладання навчальної дисципліни «Моральнопсихологічне забезпечення» в процесі підготовки майбутніх військових фахівців у ВВНЗ Сухопутних військ.

На даному етапі розвитку i трансформації Збройних Сил (ЗС) України, оптимізації системи військової освіти, ми вважаємо, що необхідно науково обгрунтувати деякі питання професійної підготовки майбутніх офіцерів Сухопутних військ ЗС України.

Слово «підготувати» означає 


\section{Питання психології}

«навчити, дати необхідні знання для чогонебудь» - таке визначення дають більшість тлумачних словників. 3 нього виходить, що «готувати» означає «формувати знання, навички і вміння для здійснення певної діяльності» [2, 98]. Напрошується питання: у чому ж полягає діяльність офіцера?

Професійна діяльність офіцерів багатофункціональна. Вона $\epsilon$ складною системою різних взаємозв'язаних видів військової праці. Деякі автори виділяють такі основні види діяльності офіцера Сухопутних військ: психолого-педагогічна (ППД), організаторська, адміністративногосподарська, бойова тощо. Всі вони проявляються в нерозривному зв'язку 3 першим видом діяльності. Зауважимо, що психолого-педагогічна діяльність, як складова професійної, займає ведуче місце у професійній діяльності офіцера. Психолого-педагогічна діяльність офіцера $\epsilon$ комплексом заходів цілеспрямованого впливу на мотиваційну, емоційно-вольову, інтелектуальну сферу особистості військовослужбовця, які забезпечують їх якісну підготовку до виконання завдань в мирний і воєнний час[3, 48].

На нашу думку, ППД офіцера $\epsilon$ відносно самостійним видом діяльності, який необхідно досліджувати і до якого необхідно готувати. Підготовку до даного, практичного виду професійної діяльності необхідно здійснювати під час викладання навчальної дисципліни «Моральнопсихологічне забезпечення». Даний вид підготовки військових фахівців в системі військової освіти, як показує військова практика, вимагає негайного корегування та уточнення.

Зауважимо, що: по-перше, для фахівців, які готуються за напрямком підготовки «Військове управління», дуже поверхнево та недостатньо викладаються питання морально-психологічного забезпечення діяльності підрозділів; подруге, із-за різної підлеглості навчальних закладів, специфіки цілей і завдань, що вирішуються, у видах Збройних Сил i родах військ відсутні єдині науковометодичні підходи викладання цієї проблематики.

На сучасному етапі становлення 3С
України метою навчання формам та методам МПЗ діяльності військовослужбовців має бути розвиток його психолого-педагогічного мислення, формування фахової і психологічної готовності з урахуванням нових вимог до особистості i діяльності офіцера, що висуваються до офіцера як професіонала.

Аналіз процесу формування у курсантів психолого-педагогічних навичок i вмінь показує, що найбільш слабким місцем в ньому $є$ встановлення міждисциплінарних зв'язків у ВВНЗ.

Існує також проблема у формуванні мотиваційної сфери діяльності курсанта, особливо командного профілю підготовки, його готовності до оволодіння знаннями та навичками виховання і навчання підлеглих.

Тому вдосконалення структури та методики викладання теорії i практики організації МПЗ діяльності військовослужбовців є одним 3 важливих напрямів забезпечення якісної підготовки курсантів до подальшого виконання своїх службових обов'язків за призначенням.

На нашу думку, основними цілями підготовки курсантів щодо організації МПЗ мають бути: вдосконалення i систематизація знань, умінь i навичок курсантів щодо організації МПЗ діяльності військовослужбовців; розвиток у них поглибленого уявлення про даний вид забезпечення діяльності підрозділів Сухопутних військ в мирний і воєнний час тощо.

У свою чергу, головними завданнями викладання основ МПЗ мають бути:

1. Оновлення i поглиблення психолого-педагогічних знань курсантів на основі оволодіння основними, фундаментальними методологічними проблемами військової педагогіки, психології, девіантології, конфліктології, які дозволяють їм вільно орієнтуватися в питаннях навчання, виховання i психологічної роботи, самостійно аналізувати морально-психологічний стан в підрозділі та окремих військовослужбовців, передбачати його подальший розвиток, як у мирний час, так i в бойовій обстановці. При цьому підготовка майбутніх офіцерів повинна 


\section{Питання психології}

здійснюватися на основі прикладних, актуальних психолого-педагогічних знань. У сукупності та оптимальному поєднанні, доповнюючи одне одного, ці знання мають практично спрямовуватися на ефективне оволодіння навичками i вміннями 3 психолого-педагогічної діяльності.

2. Формування і розвиток психологопедагогічних навичок i вмінь, які відбуваються на основі одержаних знань і відповідають основним компонентам професійної діяльності офіцера щодо організації МПЗ (оцінно-діагностичному, прогностичному, конструктивному, виконавському та ін.).

Здійснення МПЗ на основі отриманих вмінь може бути описане таким чином: від оцінно-діагностичних умінь - до прогностичних і конструктивних, а потім до виконавських. Навіть таке, дещо спрощене представлення процесу організації МПЗ діяльності військовослужбовців показує, яким складним i різноманітним комплексом вмінь має володіти майбутній офіцер.

Розвиток психолого-педагогічного мислення у майбутніх офіцерів процесуальної передумови творчого підходу в організації МПЗ. Це завдання реалізується при формуванні у курсантів військово-професійних якостей необхідних для керування підлеглими.

Формування готовності майбутніх офіцерів до психолого-педагогічної діяльності (здійснення МПЗ) здійснюється за допомогою всього комплексу заходів, що проводяться у ВВНЗ. Зауважимо, що сам процес підготовки курсантів до специфічної психолого-педагогічної діяльності 3 людьми формує у них готовність до такої роботи. Військова практика свідчить, що існує пасивне ставлення деяких випускників вищих військових навчальних закладів до навчання і виховання підлеглого особового складу, управління процесом виховання військовослужбовців. Нажаль ще зустрічається бездушшя і байдужість офіцерів до підлеглих. У процесі формування готовності до психологопедагогічної діяльності перебудовується свідомість i психіка курсантів щодо прагнення до спілкування, вміння слухати і чути підлеглого, гуманізації відносин в процесі служби і поза нею. Він сприяє розумінню курсантами суспільної важливості і необхідності МПЗ, вирішення суперечностей військово-педагогічного процесу в частині (підрозділі). Курсанти мають отримувати навчально-практичні завдання з урахуванням їх індивідуальних особливостей і практики проведення МПЗ діяльності військовослужбовців в Збройних Силах. Науково-педагогічні працівники повинні створювати (моделювати) під час занять ситуації психологічної напруги, дискомфорту i стресу 3 метою навчання майбутніх офіцерів виходу 3 них. Підтримка навіть невеликих успіхів недостатньо упевнених в собі курсантів, схвалення їх старань, щонайменших досягнень має бути елементом педагогічної техніки кожного викладача у ВВНЗ.

Для вирішення цих завдань пропонується наступне.

По-перше, вважати підготовку офіцерських кадрів у ВВНЗ з питань МПЗ невід'ємним компонентом професійної підготовки військових фахівців. Викладання основ МПЗ повинне здійснюватися на кафедрі психології i педагогіки (МПЗ), де необхідно утворити предметно-методичну комісію 3 питань морально-психологічного забезпечення військ.

По-друге, в контексті майбутніх реорганізацій структур з МПЗ ввести на всіх спеціальностях (особливо командного профілю) викладання окремої навчальної дисципліни «Морально-психологічне забезпечення». Зважаючи на іiі комплексний i міжпредметний характер викладання повинне вестися в нерозривному зв'язку із вивченням інших гуманітарних загальнопрофесійних i військово-професійних дисциплін, особливо таких, як військова педагогіка, військова психологія, військова девіантологія, тактика, управління повсякденною життєдіяльністю військ, але не дублювати їх, а забезпечувати спадкоємність і логічну послідовність, в максимальній мірі відображаючи 


\section{Питання психології}

специфіку підготовки фахівців 3 питань управління МПЗ підрозділів. Об'єктом вивчення даної дисципліни $є$ духовна сфера діяльності військ в різних умовах обстановки, а предметом - основи, закономірності, завдання, зміст, напрями i шляхи здійснення МПЗ військ в мирний час, в ході війни, виконання миротворчих місій, a також організаторська i виконавська діяльність офіцерських кадрів щодо підтримки високого моральнопсихологічного стану особового складу.

На нашу думку, кількість часу, що відводиться на вивчення навчальної дисципліни «Морально-психологічне забезпечення» під керівництвом викладача, має складати не менше 120 годин. На жаль, на сьогоднішній день, наприклад, в начальних планах підготовки офіцерівбакалаврів командного профілю (механізовані, танкові, інженерні війська тощо) у Національній академії сухопутних військ на викладання дисципліни «МПЗ підготовки i застосування ЗС України» відводиться всього 60 аудиторних годин!

По-третє, необхідно звернути особливу увагу на розробку програми навчальної дисципліни та робочої програми навчальної дисципліни вивчення питань МПЗ. Зауважимо, що в сучасних умовах командиру належить докласти чималі зусилля для створення позитивного настрою i здорового психологічного клімату у військових колективах. Випускники військового навчального закладу повинні вміти аналізувати i оцінювати військово-політичну, моральнопсихологічну і інформаційну обстановку, управляти військами 3 урахуванням соціологічних, психолого-педагогічних, правових і інших чинників, прогнозувати тенденції i перспективи розвитку військової теорії і практики в галузі морально-психологічного забезпечення. Тому доцільно, на наш погляд, в навчальних планах передбачити виконання курсової роботи, а в завданнях на розробку кваліфікаційних робіт відображати питання організації і проведення МПЗ діяльності підрозділів Сухопутних військ. На іспитах в білети 3 тактико-спеціальних дисциплін необхідно включити окреме питання 3 морально-психологічного забезпечення військ. При відпрацюванні комплексних тактичних завдань, проведенні командноштабних навчань і військових ігор слід виділяти навчальний час на вироблення у курсантів навичок в організації МПЗ військ за різних умов обстановки.

По-четверте, 3 метою підвищення ефективності i якості навчання необхідно удосконалити навчально-матеріальну базу, інформаційне і навчально-методичне забезпечення освітнього процесу. Для цього на кафедрах, що здійснюють навчання 3 питань МПЗ доцільно створити науководослідні групи (лабораторіі) МПЗ, на які покласти ведення наукової роботи і розробку методичних і навчальних матеріалів з питань морально-психологічного забезпечення. В міру можливості необхідно створювати спеціалізовані класи (кабінети). Навчальнометодичне забезпечення викладання цієї навчальної дисципліни може включати: підручник, практикум (завдання і вправи) i довідково-інформаційні матеріали 3 військ. Це дозволить підвищити якість викладання основ МПЗ, розвинуги ініціативу і творчість тих, хто навчається. У крайньому випадку (якщо фінансово-економічні умови не дозволяють більшого) можна обмежитися випуском уніфікованих підручників (посібників) для ВВНЗ.

Навчання курсантів з організації МП3 діяльності військовослужбовців у ВВН3 має будуватися як цілеспрямована організована взаємодія керівного та науково-педагогічного складу навчального закладу і майбутніх офіцерів. Особливе місце при цьому відводиться науковопедагогічним працівникам провідної кафедри, які безпосередньо здійснюють організацію і проведення занять 3 питань МП3. Курсанти повинні виступати активними учасниками цього процесу як особи, що самоорганізовуються i саморозвиваються, як суб'єкти підготовки до практичного здійснення МПЗ діяльності військових підрозділів.

Результати та дискусії. Результатом навчання основам організації і проведення МПЗ має бути розвинена педагогічна культура, широка психолого-педагогічна ерудиція і світогляд, безумовно виражена 


\section{Питання психології}

психолого-педагогічна спрямованість особи, особливе відношення майбутніх офіцерів до психолого-педагогічної роботи 3 підлеглими. Цей результат має бути поєднанням соціально значущих мотивів, психолого-педагогічних знань, навичок, вмінь i якостей особи, які забезпечать успішне здійснення МПЗ в ході проведення Операції об'єднаних сил, в сучасних умовах поступового переходу 3С України на комплектування військовослужбовцями військової служби за контрактом та активізації процесу євроатлантичної інтеграції України.

Його суттю має бути оволодіння курсантами знаннями, навичками i вміннями необхідними для психологопедагогічної діяльності, адекватної майбутньому посадовому призначенню.

Особливістю викладання цієї навчальної дисципліни $€$ інтеграція знань про людину з різних наук, використання практичного військового досвіду, поєднання психолого-педагогічної теорії iз практикою, військової психології 3 військовою педагогікою, педагогічної підготовки 3 психологічною. Поглиблена підготовка майбутніх офіцерів командного профілю до майбутньої роботи з людьми буде позитивно впливати на всю атмосферу у ВВНЗ та сприяти гуманізації і демократизації стосунків.

\section{Висновки та перспективи} подальших досліджень. Отже, створення єдиної, універсальної науково-методичної бази викладання основ МПЗ діяльності військовослужбовців дозволить підготувати курсантів будь-якого ВВНЗЗС України для успішного виконання завдань щодо формування та підтримки високого морального духу і психологічної стійкості військ (сил).

Таким чином, можна 3 упевненістю стверджувати, що навчання курсантів основам організації та проведення морально-психологічного забезпечення діяльності військ має стати невід'ємною і важливою складовою їх професійної підготовки, і вимагає до себе особливої уваги і подальшого вдосконалення.

Перспективними

напрямками дослідження порушених питань можуть бути: обгрунтування цілей, принципів, форм i методів підготовки майбутніх офіцерів тактичного рівня до проведення заходів МПЗ; розробка комплексу навчально-методичних матеріалів для науково-педагогічних працівників, курсантів щодо організації підготовки майбутніх офіцерів до організації та проведення заходів МПЗ тощо.

\section{Список використаних джерел}

1. Наказ Генерального штабу Збройних Сил України від 27.04.2018 року №173 «Про затвердження Настанови з морально-психологічного забезпечення підготовки та застосування Збройних Сил України».

2. Романишин А.М. Проблеми підготовки курсантів у вищих військових навчальних закладах / А. М. Романишин // Педагогіка і психологія професійної освіти: науково-методичний журнал. - 2011. №2. C. 97-103.

3. Романишин А.М. Зміст педагогічного поняття “військова діяльність" / А. М. Романишин // Збірник наукових праць Національного університету оборони України. - 2011. №3. - С. 47-51.

\section{References}

1. NakazHeneralnohoshtabuZbroinykhSylUkrainy (2018) №173 «ProzatverdzhenniaNastanovy z moralno-psykholohichnoho zabezpechenniapidhotovkytazastosuvanniaZbroinykhSylUkrainy»)[FreedomoftheGeneralAssemblyofZbroinykhS ylUkrainy (2018) №173 «ProzatverdzhenniaNastanovy $z$ moralno-psykholohichnoho zabezpechenniapidhotovkytazastosuvanniaZbroinykhSylUkrainy»]. Kyiv [inUkrainian].

2. Romanyshyn A.M. Problemy pidhotovky kursantiv u vyshchykh viiskovykh navchalnykh zakladakh / A. M. Romanyshyn // Pedahohika i psykholohiia profesiinoi osvity: naukovo-metodychnyi zhurnal. 2011. №2. - S. 97-103.

3. Romanyshyn A.M. Zmist pedahohichnoho poniattia "viiskova diialnist" / A. M. Romanyshyn // Zbirnyk naukovykh prats Natsionalnoho universytetu oborony Ukrainy. - 2011. №3. - S. 47-51. 


\section{Питання психології}

\section{Резюме}

Романишин А. кандидат педагогических наук, доцент Наииональная академия сухопутных войск имени гетмана Петра Сагайдачного ORSID0000-0003-3115-5999

Неурова А. кандидат психологических наук, Национальная академия сухопутных войск имени гетмана Петра Сагайдачного ORSID: 0000-0002-1220-8613

\section{ПСИХОЛОГО-ПЕДАГОГИЧЕСКИЕ УСЛОВИЯ ПРЕПОДАВАНИЯ УЧЕБНОЙ ДИСЦИПЛИНЫ «МОРАЛЬНО-ПСИХОЛОГИЧЕСКОЕ ОБЕСПЕЧЕНИЕ» В ВЫСШИХ ВОЕННЫХ УЧЕБНЫХ ЗАВЕДЕНИЯХ}

В статье представлень результаты анализа основных психолого-педагогических условий эффективной организаџии преподавания учебной дисииплины «Морально-психологическое обеспечение» в процессе подготовки будущзих военных специалистов в выстих военных учебных заведениях Министерства обороны Украинь и определены пути достижения эффективности реализации психолого-педагогических условий организации ее преподавания.

Ключевые слова: морально-психологическое обеспечение; подготовка; профессиональная деятельность офицера; психолого-педагогическая деятельность; психолого-педагогические условия.

\section{Summary}

Romanishin A. Candidate of Pedagogical Sciences, Associate Professor National Academy of Army Forces n.a. hetman Peter Sagaydachny Neurova A. Ph.D.,Candidate of Psychological Sciences National Academy of Army Forces n.a. hetman Peter Sagaydachny

\section{PSYCHOLOGICAL AND PEDAGOGICAL CONDITIONS OF "MORAL-PSYCHOLOGICAL SUPPORT" EDUCATIONAL PROGRAM IN HIGHER MILITARY EDUCATIONAL INSTITUTIONS}

Introduction. The article presents the results of the analysis of the main psychological and pedagogical conditions for the effective organization of teaching the discipline "Moral and psychological support" in the process of preparation of future military specialists in higher military educational institutions of the Ministry of Defense of Ukraine.

Purpose. The purpose of the article is to conduct theoretical analysis of scientific sources on the problem under investigation, to determine the ways of achieving the effectiveness of the implementation of the psychological and pedagogical conditions for organizing the teaching of the discipline "Moral-psychological support" in the process of training future military specialists in higher military educational institutions of the Ministry of Defense of Ukraine.

Methods. Empirical methods of observation, questioning and questioning were used to solve the problems of education.

Originality. The article substantiates the basic psychological and pedagogical conditions of an effective organization of teaching the discipline "Moral-psychological support" in the process of preparation of future military specialists in higher military educational institutions of the Ministry of Defense of Ukraine. The ways to achieve implementation of the psychological and pedagogical conditions of teaching the discipline "Moralpsychological support" in higher military educational institutions are revealed. The main tasks of teaching the fundamentals of moral and psychological support in higher military educational institutions are determined. The features of teaching this discipline are as follows: integration of knowledge about a person from different sciences, the use of practical military experience, the combination of psychological and pedagogical theory with practice, military psychology with military pedagogy, pedagogical training with psychological. It is determined that in-depth training of future officers of the command profile for future work with the people will positively influence the atmosphere in the higher military educational institutions of the Ministry of Defense of Ukraine and promote humanization and democratization of relations.

Conclusion. Development of unified, universal scientific and methodological base for teaching the bases of the military-intelligence service activities will allow the training of cadets from any higher military educational institutions of the Armed Forces of Ukraine for the successful accomplishment of tasks in support of high moral standards and psychological stability of the forces).

Keywords: educational discipline, moral and psychological support, training, professional activity of the officer, psychological and pedagogical activity, psychological and pedagogical conditions, teaching, readiness. 